\title{
Working Group Reports
}

\author{
"Poplar management is increasingly important in \\ Canadian forestry. Silvicultural treatments to im- \\ prove stands of native poplars must be considered \\ alongside treatments to release softwoods from \\ poplar competition. Intensive silviculture is needed to \\ grow the new forest of short rotation hybrid poplars \\ which are now being developed. The two papers \\ which follow were presented at the Silviculture Work- \\ ing Group session at the Annual Meeting in October, \\ 1979." \\ J. C. Lees \\ Chairman, W.G.8., Silviculture
}

\section{Intensive Management of Hybrid Populus'}

\author{
H. W. Anderson ${ }^{2}$
}

The word "intensive", as in "Intensive forestry", is an adjective and therefore a relative term. Its meaning may reflect its terms of reference and depend, for example, on the number of hectares under management compared with budgetary and manpower sources available, with the nature of the forests, that is wild forest or plantation, with the land productivity, and its accessibility. What may be one person's intensive husbandry may be viewed by another as intensive exploitation.

Perhaps some of the common elements that silviculturists might agree upon are a part of intensive forestry involve selection and control of stocking levels and rotation lengths, fertility and pest management, land preparation, gene-pool manipulation, and cost-effectiveness.

With the space available, I shall discuss mainly a system of intensive forestry that is being developed and practiced in Ontario. This is not meant to suggest that it is the best system, but certainly the only one that justifies this discussion.

I would like to present some observations on the shortrotation concept of hybrid Populus management and will try to illustrate where possible with specific reference to aspen.

\section{Aspen Improvement}

The genus Populus may offer greater possibilities for genetic improvement than any other genus of forest trees. They have great ecological amplitude and grow on a wide variety of soils and climatic conditions in Canada. Studies of natural variation, breeding experiments, and estimates of heritability indicate great potential for the improvement of growth, form and a number of wood properties. A rapid genetic gain can be obtained by selection and breeding followed by clonal propagation.

When properly selected, hybrid poplars have fast vigorous growth, a uniform predictable quality, can be vegetatively propagated, and will respond favourably to intensive culture. They also have the ability to regenerate by coppicing or stump sprouting. Of course many of these

\footnotetext{
1 Paper presented to the Silviculture Working Group at the Annual Meeting of Canadian In. stitute of Forestry, Jasper, Alberta, Sept. 30-Oct. 4, 1979.

2Research Scientist, Ontario Forest Research Centre, Ministry of Natural Resources, Maple, Ontario.
}

characteristics of poplar hybrids have been known tor 300 years, and poplar plantations have existed in Canada since 1909.

Interspecific breeding of aspens was initiated in Ontario in 1935 by Dr. Carl Heimburger, but exploration of the potential of intensive management was not started until 1970 by his successor, Dr. Louis Zsuffa.

The most useful sections of the genus Populus are the Leuce or aspen group, the Tacamahaca or balsam poplars and the Aigeiros section or cotton-woods. Interspecific hybridization is fairly easy within sections (e.g. p. deltoides $x$ nigra $=P . \times$ euramericana) and between Aigeiros and Tacamahaca sections, but are more predictable when involving section Leuce (e.g. P. deltoides $\mathrm{x}$ tremula).

Related poplar species, when crossed, often produce offspring with hybrid vigour or "heterosis". Most frequently, such heterotic hybrids are produced from parental species that came from geographically distant areas, or relatively isolated regions. Thus, the most promising aspen-type hybrids are those such as European $P$. alba $x$ native $P$. grandidentata, or $P$. tremula $\times$ tremuloides. Outstanding individual trees have come from advanced crosses between $P$. canescens (which is a wild hybrid of $P$. alba $\times$ tremula) and the hybrid $P$. alba $\times$ grandidentata (CAG for short).

In practice hybrid seedlings produced by artificial interspecific pollination are outplanted in progeny-tests, with outstanding individuals being selected, by a variety of criteria, to be developed as clones. Clones are genetic replicates reproduced vegetatively by stem cuttings and are set out in performance tests. Cottonwoods and balsam poplars root relatively easily and unrooted cuttings can be planted. The aspen types root poorly or unpredictably and usually rooted cuttings are required for establishment. In other cases, aspen hybrids are evaluated as populations of seedlings derived from a known parental cross but which show some performance variability due to differing genetic linkage. Aspen propagules can also be readily produced in the greenhouse from root suckers and grown in tubes for later transplanting. In all cases, the resulting outstanding clones or individuals are selected for mass propagation and pilot scale management trials.

The high growth potential of hybrid aspen clones cannot be used in practice without having well-established procedures for handling and rooting of aspen cuttings. It has 
been noted that many aspen clones that root poorly and inconsistently in field conditions, show better success in greenhouse culture. Many aspen clones have preformed root primordia or "root bumps" on the stem which appear to indicate potential rooting ability. The problem in many instances is one of simply encouraging growth in these meristems, and not necessarily one of inducing the formation of root initials in the host tissue. Synthetic auxin treatments, combined with selective hybridization, appear to offer some future promise in developing an operational planting system for aspen, but for the present, plantation performance data are rather limited for aspen because of the effort required to establish trials.

\section{Management Systems}

Several management systems, each with its own peculiar objectives, are being tested in Ontario. Two extreme examples involve a "forest type plantation", in which improved stock is planted in forest cutovers with minimum preparation. Such plantations do not perform as well as intensively managed systems but, if correctly selected and site-matched, will usually outperform the native regeneration. On the other hand, a "poplar polyculture" system is being tested where the poplar is interplanted as a nurse crop for a more valuable species such as black walnut. This is attempted only on the best sites under favourable growing climates.

Most of the plantings are designed to produce log-sized trees for veneer, pole-sized trees for pulpwood, or small sapling-sized coppices suited to a variety of chemical uses.

In establishing such plantations complete site preparation is required. Mechanical site preparation, initially ploughing followed by double discing, is carried out the year previous to planting. Frequently herbicides, such as Eptam, are incorporated in this stage, with a later preplanting treatment of simazine/terbacil to prevent weed development. Considerable clonal variation in herbicide tolerance has been noted and requires much further study.

While clone-site interactions are incompletely understood at present, management sites are mapped through soil surveys in advance, and clones are assigned to site types according to present knowledge of clonal requirements. This documentation allows us at least to learn from our mistakes. Fertilization requirements are perhaps even lessperfectly known, but routine applications of N-P-K and ammonium nitrate formulations, among others, are made in cutting-stool beds to maximize stock production. Here too we have found that pushing too much nutrient can predispose poplar to uncharacteristic frost damage and much has yet to be learned in this area. At present greenhouse pot-culture experiments are exploring this aspect attempting to give direction to this requirement. Also, recent field tests using activated mill sludge and/or sewage effluent are being closely monitored.

Spacing and rotation length greatly influence productivity and tree characteristics, and are prescribed according to specific objective of management. Veneer-type or "longrotation" plantations are managed on 20- to 30-year rotation, and are established at 4- to 6-metre spacing with rooted stock to increase survival probability, since each tree is comparatively valuable. Weed control is required for several years until the trees capture the site. Recently we have experimented with a procedure common in Europe known as a "dual crop system" in which corn, potatoes, squash or buckwheat is grown in the wide corridors for the first few years. This cash crop reduces costs, helps to control weeds and performs a weed-control function.

Pulpwood or "short-rotation" plantings require similar treatment but are initiated at 3- to 4-metre spacings, using unrooted cuttings, and are designed to give normal pulpwood trees (about $20 \mathrm{~cm}$ dbh) when harvested at 10 years. A whole-tree chipping demonstration of 6-year-old $P$. alba aspens grown at 4-metre spacing yielded $115 \mathrm{~m} 3 / \mathrm{ha}$ (12.7 cords/acre), with a projected equivalent yield at 10 years of $230 \mathrm{~m}$ /ha ( 26 cords/acre). The stand is automatically regenerated from stump or root sprouts which usually need thinning.

Examples of yields of experimental plantations of different clonal origin include volumes approaching $250 \mathrm{~m} 3 /$ ha (or 28 cords/acre) in 10 years, and $500 \mathrm{~m}^{3} / \mathrm{ha}$ ( 56 cords/acre) in 20 years. Converting such values to estimated oven-dry biomass indicates similar productivities for a variety of clones. Average heights and diameters of poplar hybrids at age 10 are comparable to yield table data for 30 -year-old native aspen, and yields are comparable to 40-year-old natural stands. Yields at a fixed rotation length are affected by a clone spacing interaction and several current studies are attempting to optimize clonal spacing and rotation options to give specified yields and product sizes at varying investment periods.

A more recent concept, often termed "minirotation" or "poplar farming", involves closely-spaced coppices intensively managed on a 1- to 3-year rotation, much like an agricultural crop. Unrooted cuttings are planted in cultivated, fertilized and perhaps irrigated soil at spacings such as $0.3 \times 0.9 \mathrm{~m}$ ( $1 \times 3$ feet). The clone - spacing rotation interaction is very strong and should be viewed as a continuum from which a choice is made for particular endproducts. In this system, the vegetative growth produced after planting (about one metre high) is cut back the following winter. The resulting coppices usually grow much faster, attaining heights of up to $4 \mathrm{~m}$ in the first year, and $6 \mathrm{~m}$ in the second. Yields vary with clonal selection. Studies to date suggest that aspens such as $P$. grandidentata $\times$ alba cl. 88 at $6.4 \mathrm{odt} / \mathrm{ha} / \mathrm{yr}$, and $P$. canescens $\mathrm{cl}$. C147 at $11.2 \mathrm{odt} / \mathrm{ha} / \mathrm{yr}$ are promising. Triploid $P$. $x$ euramericana such as clone DN25 (17 odt/ha/yr in 2 yr rotation) would also be suitable. A critical factor in sprout regeneration is stump or stool longevity, and data suggest that both clone and harvesting method affect stump deterioration. It now appears that at least four 2-year harvests are possible without significant yield reduction, and consequent necessity to replant.

\section{Costs}

The costs involved in such intensive management are considerable as can be seen from Table 1. It seems that cost per ton of minirotation wood is about double that for short rotation. Much of this difference is due to the costs of

Table 1 Budget estimates for hybrid poplar3

\begin{tabular}{lcc}
\hline & $\begin{array}{c}\text { Minirotation } \\
\text { Estimated average }\end{array}$ & $\begin{array}{c}\text { Short rotation } \\
\text { cost } \mathbf{( \$ / a c / y r )}\end{array}$ \\
\hline Materials & 91.00 & 12.83 \\
Site prep & 42.80 & 2.32 \\
$\&$ planting & 32.00 & 4.58 \\
$\begin{array}{l}\text { Pest control } \\
\text { fertilizer }\end{array}$ & & \\
Harvesting & 44.00 & 8.86 \\
Misc. & 90.00 & 66.00 \\
Total & 299.80 & 94.59 \\
Average cost/ton & 24.98 & 11.82 \\
& $(12$ green tons/ac) & (8 green tons/ac) \\
\hline
\end{tabular}

3Data condensed from:

Pfeiffer, W.C. 1978. Economic potentials of hybrid poplar-based fibre production as an agricultural enterprise in eastern Ontario. Ont. Min. Natur. Res., Timber Sales Branch (unnumbered), $50 \mathrm{pp}$. 
planting trees at such high densities, about 15,000 stems/acre. The differential will tend to decrease as yields improve through clonal selection, as more efficient planting procedures evolve and as the value of "Non-fibre" products such as liquid fuels and protein extracts for example, become better established. The minirotation expertise is at the stage of corn culture 50 years ago and it should be expected that some of the current corn expertise should be directly transferable to poplar. Provisional biomass estimators and growth simulation models developed for our plantations should provide a starting basis for optimizing the system.

\section{Discussion}

Carl Heimburger was quoted a few years ago as saying "poplar growing in eastern Ontario is largely a series of frustrations interrupted by a few promising results". This may still be true. We have achieved some outstanding successes and some miserable failures. We have solved many problems only to find that, through intensification, we create more. For example, the intensive utilization of foliage removes large quantities of nutrients from the site which ultimately will have to be replaced. The impact of insects such as shoot sawfly and diseases like bacterial canker become more important as investments and acreages increase. These problems can be met and handled in part by genetic engineering, but it is obvious that the system will always be a dynamic, evolving one.

In my view, intensive poplar culture will not make instant millionaires out of any of us. The attractive virtues of the system must be balanced against the considerable investment and management costs. The "take home" money may not be out of line with conventional forestry operations.

However it does give us two unique things. First, it contributes a large biomass with characteristics of a known and predictable nature. Second, it is produced in a very short time. In eastern Ontario, with some 1 million idle farm acres beside mills with wood shortages, and in these days of tight money, inflation and inflexible economic opportunity, time is one precious commodity that is very difficult indeed to purchase.

\title{
The Effects of Scarification on Trembling Aspen in Northern Ontario: 1
}

\author{
A preliminary Report \\ by \\ David H. Weingartner ${ }^{2}$
}

\section{Introduction}

The Northern Forest Research Unit located at Thunder Bay, Ontario, is a field unit of the Ontario Forest Research Centre. Research programs at the Unit are aimed at improving the management of balsam fir (Abies balsamea (L.) Mill), white spruce (Picea glauca (Moench) Voss.), black spruce (Picea mariana (Mill.) BSP) and trembling aspen (Populus tremuloides Michx.).

Prior to 1975 the main emphasis of the aspen research program was on the quality of the large quantities of second growth trembling aspen that became established following harvest of the old-growth forest. Some of this work was done as co-operative projects with the federal government, particularly that of Dr. J. T. Basham, of the CFS at the Great Lakes Forest Research Centre in Sault Ste. Marie, Ontario. Early studies dealt with the defect and associated

\footnotetext{
1. Presented at the 1979 Annual Meeting of the Canadian Institute of Forestry Silvicultura Working Group Session Jasper, Alberta October 1, 1979

2 Ontario Ministry of Natural Resources, Northern Forest Research Unit, Thunder Bay Ontario
}

pathogens of single trees, and progressed to the study of the variation of growth, defect, and pathogens among aspen clones (Basham and Navratil 1975; Kemperman et al. 1976; Kemperman et al. 1978).

From 1975 to the present increased emphasis has been placed on the effects of silvicultural practices on the growth, development, and quality of young second growth aspen. Studies have been established to evaluate the effects of herbicide application, scarification and thinning. Studies of the internal quality following herbicide application and scarification are being conducted by Dr. Basham.

During the period between 1975 and 1977 four scarification projects were established in northern Ontario to evaluate the effects of scarification on the quantity and quality of aspen regeneration.

\section{Methods}

The areas selected for study were either hardwood stands, or mixedwood stands with a high percentage of aspen. Furthermore, the areas selected were harvested during the dormant season, as suckering is maximized following a dormant season harvest (Zehngraff, 1946a). 
Table 1. Treatments, sucker development at the time of scarification, and description of scarification drags, by area.

\begin{tabular}{|c|c|c|c|c|}
\hline \multirow{2}{*}{$\begin{array}{l}\text { Area } \\
\text { No. }\end{array}$} & \multicolumn{2}{|c|}{ Treatment } & \multirow{2}{*}{$\begin{array}{l}\text { Sucker } \\
\text { development }\end{array}$} & \multirow[b]{2}{*}{ Drag description } \\
\hline & Season & Intensity & & \\
\hline 1 & 2 & 3 & 4 & 5 \\
\hline \multirow[t]{2}{*}{175} & Sring & Light & None & 26 spiked links (90-lb. links) \\
\hline & Fall & $\begin{array}{l}\text { Light } \\
\text { Control }\end{array}$ & Complete & 11 spiked links (90-lb. links) and 5 unspiked links (20-lb, links) \\
\hline \multirow[t]{4}{*}{176} & Spring & Light & None & 15 spiked links (60-lb. links) and mini-barrel \\
\hline & & Heavy & None & $\begin{array}{l}\text { 24-inch diameter shark-finned barrel, water filled; } 20 \text {-inch diameter } \\
\text { shark-finned barrel, empty; and } 17 \text {-inch diameter shark finned barrel, } \\
\text { water-filled }\end{array}$ \\
\hline & Fall & Light & Complete & Same as spring light \\
\hline & & $\begin{array}{l}\text { Heavy } \\
\text { Control }\end{array}$ & Complete & Same as spring heavy \\
\hline \multirow[t]{3}{*}{177} & Spring & Light & Initiated & 14 spiked links (55-lb. links) \\
\hline & & & Initiated & $\begin{array}{l}14 \text { spiked links (55-lb. links), 12-inch diameter shark-finned barrel, } \\
\text { cement-filled; and } 12 \text {-inch diameter flanged barrel, cement-filled }\end{array}$ \\
\hline & & Control & & 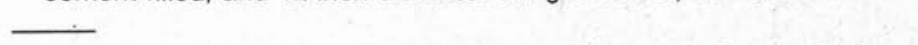 \\
\hline \multirow[t]{4}{*}{276} & Spring & Light & None & $\begin{array}{l}\text { 24-inch diameter shark-finned barrel, water-filled; and } 15 \text { spiked links } \\
\text { (55-lb. links) }\end{array}$ \\
\hline & & Heavy & None & $\begin{array}{l}\text { 30-inch diameter shark-finned barrel, water-filled; } 24 \text {-inch diameter } \\
\text { shark-finned barrel, water-filled; and } 15 \text { spiked links ( } 55 \text {-lb. links) }\end{array}$ \\
\hline & Fall & Light & Complete & Same as spring light \\
\hline & 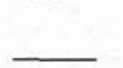 & $\begin{array}{l}\text { Heavy } \\
\text { Control }\end{array}$ & Complete & Same as spring heavy \\
\hline
\end{tabular}

Table 1 lists by study area the season and intensity of treatment, sucker development and a description of the scarification drags used to treat the study areas.

Treatments were individually applied to plots of approximately $4,000 \mathrm{~m}^{2}$ in area and replicated three times in a randomized complete block design. Evaluation of the treatments was accomplished by assessing randomly located permanent clusters of five $2 \times 2 \mathrm{~m}$ sample plots. A total of 16 clusters per treatment plot were assessed at study area No. 175, and 10 clusters per treatment plot were assessed at the three other study areas. The data collected for each sample plot, within a cluster, included aspen stocking and height of the tallest dominant aspen sucker. A count of aspen suckers was made for the first and fifth sample plot of each cluster to determine sucker density. Aspen suckering was assessed at the end of the first and second growing seasons after treatment (stand age two and three years for the fall treatments applied at the end of the first growing season), and will be reassessed following the fifth growing season from harvest.

The light scarification drags used to treat the study areas were selected to break down logging slash and disrupt the organic layer over the mineral soil, while minimizing damage to the parent root systems and aspen suckers already present in the case of treatments applied during and following sucker development. The function of the heavy drags (areas Nos. 176, 276, 177) was to achieve maximum break down of slash, and to mix the organic mantle with the mineral soil, irrespective of the consequences to the parent root systems or existing suckers. The treatments applied to areas Nos. 176,276 and 177 are representative of the site preparation treatments applied to upland sites prior to artificial regeneration with spruce, and as a result can be evaluated in terms of the effects of operational scarification on aspen regeneration. As in operational scarification two or three drags were attached to a toolbar (1.83-m spacing) and pulled by a suitable prime mover. Parallel passes were made along the long axis of the treatment plot until the entire plot was treated. The sucker conditions at the time of treatment were selected to cover three situations which may be encountered in the field: no suckers present, sucker growth initiated, and one full season's growth. Most operational site preparation for spruce regeneration in Ontario is applied after the suckers have completed at least one season's growth.

\section{Results and Discussion}

The assessment results for the areas' mean stocking, density, relative density and dominant height by stand age and treatment are summarized in Table 2.

Control plots on all areas were well stocked and had a high density of aspen suckers at the end of the first growing season following harvest (stand age one year). The areas' mean stocking for the controls ranged from $91 \%$ to $96 \%$, with a density range of 39.0 to 46.8 thousand stems/ha. All spring scarification treatments, irrespective of intensity, or sucker development at the time of treatment (Table 1), increased stocking at least $4 \%$ and a maximum of $9 \%$ over the respective control means. Ground disturbance typically increases stocking as reported in the literature (Zehngraff 1946b; Zillgitt 1951; Maini and Horton 1966).

Spring scarification (light and heavy), applied prior to suckering, resulted in increased sucker density. Gains of $60 \%$ to $78 \%$ over the control means were achieved by light spring scarification, and heavy spring scarification resulted in a $89 \%$ to $117 \%$ increase over the control density. The maximum mean density was 97,000 stems/ha (area No. 276) for the heavy spring scarification treatment and the minimum mean density was 71,800 stems/ha (area No. 276) for light spring scarification.

Spring scarification during initial sucker production (area No. 177), resulted in first-year densities that were $2 \%$ greater than, and $16 \%$ less than, the control mean, for the light and heavy treatments respectively. Compared with treatments applied prior to suckering the minor increase and appreciable decrease in density over the control is attributed to the mechanical action of the drags on existing suckers, and the inability of the parent root systems to produce additional suckers before physiological and/or microclimate conditions became unfavourable for sucker production.

Stocking increased slightly by the end of the second growing season for most controls and spring scarification treatments. The lowest stocking for any area was $88 \%$ for the control at area No. 177. Sucker density for the controls, and spring scarification treatments on all areas decreased by the end of the second growing season, as did the relative sucker density of the plots scarified prior to suckering (average decrease .42). Plots scarified during suckering 
Table 2. Area means of stocking, density, relative density, and dominant height by stand age, treatment, and sucker development.

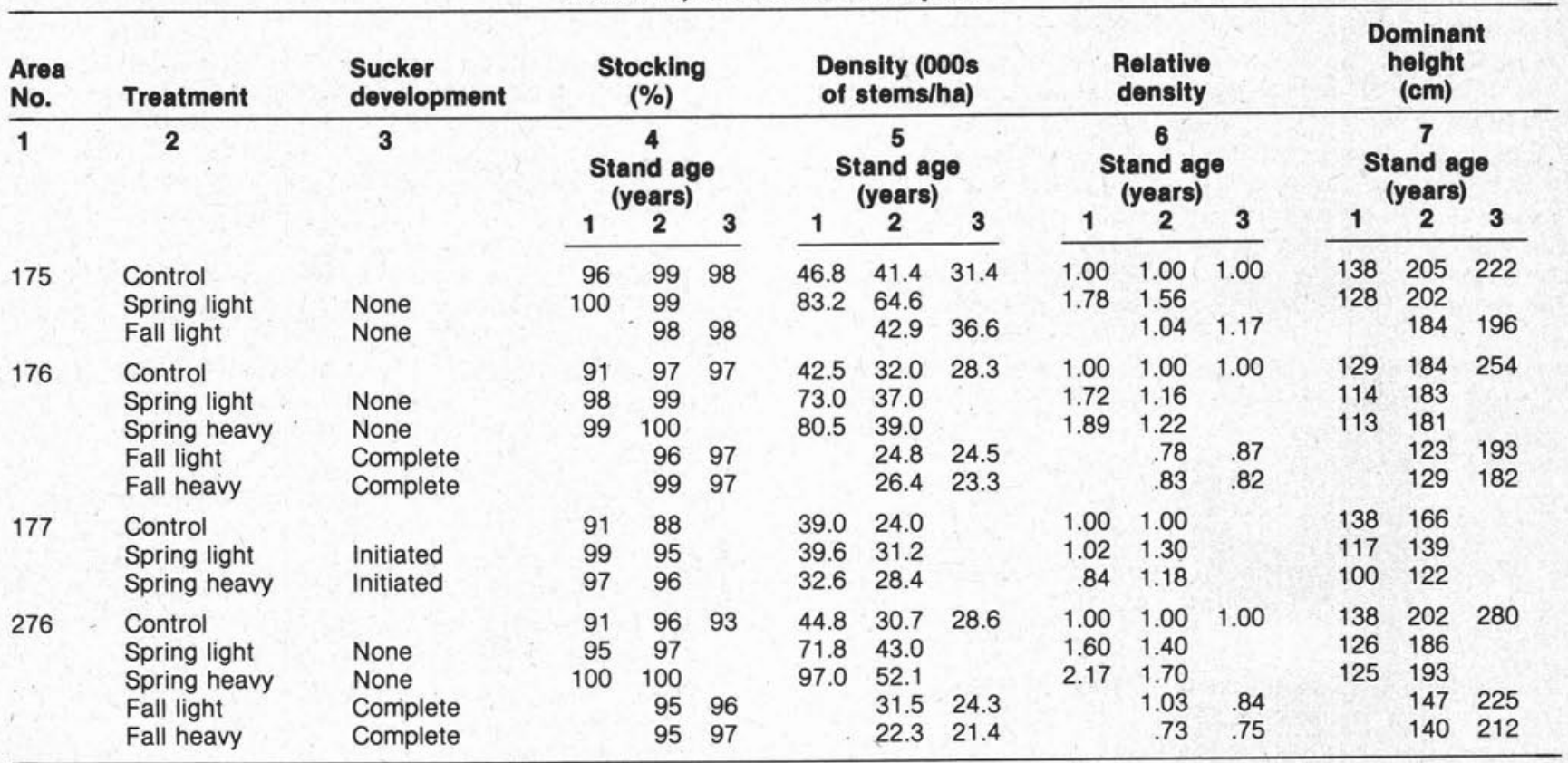

(area No. 177) showed an average increase of .31 over the first year results.

The decrease in the relative sucker density exhibited by the spring treatments applied prior to suckering indicates that the gains in density achieved by the treatments are short-lived, and that the actual density is approaching that of the controls. Conversely, spring scarification applied following initial suckering exhibited a slower decrease in actual density, hence the increase in relative density. This is a reflection of decreased competition between individual suckers due to the paths created by the drags (e.g. effective release on one side).

Fall scarification (light and heavy) resulted in little gaın or loss in the per cent stocking when compared with the respective control the first year after treatment (stand age two years). However, in the second year following treatment a trend toward an increase or maintenance of stocking was exhibited by the fall scarified plots at areas Nos. 276 and 175; whereas the control stocking decreased slightly. Sucker density following fall scarification was generally less than that of the controls at stand age two and three years. This would be expected as the existing suckers were damaged by the treatments. Increases and decreases in the relative densities of the fall treatments are about equal, indicating that the actual densities are decreasing at approximately the same rate as the controls.

Irrespective of the timing or intensity of treatment, all scarification treatments resulted in mean dominant heights that were less than those of the controls. A comparison of dominant heights at a stand age of two years indicates that scarification treatments applied at the end of the first growing season or after initial suckering in the spring may have had a slightly greater impact on height growth than treatments applied before suckering. This result would be expected due to the mechanical action of the drags on the existing suckers, but this is only a partial explanation of a possible cause-effect relationship. The reduced height growth resulting from treatments applied prior to suckering cannot be explained as easily even though the mechanical action of the treatments on the parent root systems may, in part, be a causal factor. Sandberg (1951) reported a reduced height for aspen suckers on treated plots compared with a control. In one of his treatments the litter was removed (without apparent damage to the parent root system). His partial explanation for the reduced height was that the suckers arose at a lower level in the soil profile. An alternative explanation, to account for the reduction in height growth, is increased moisture stress within the suckers due to two factors: 1) the increased number of suckers requiring moisture for growth, and 2) increased evaporation from the soil surface, resulting from destruction of the insulating litter layer.

\section{Conclusions}

Based on the preliminary data (Table 2) the following tentative conclusions are made pending future assessment of the areas and statistical analysis of all the data. 1) Scarification applied prior to suckering increases both the per cent stocking and density of aspen suckers compared with controls, with the greatest increase resulting from heavy scarification; and 2) all scarification results in a reduction in dominant height with the greatest impact resulting from treatments applied following initial sucker development.

\section{References}

Basham, J. T., and S. Navratil, 1975. An assessment of the pathological quality of aspen suckers established on cutovers in Ontario. Can. Forest. Serv., Sault Ste. Marie, Ont. Rep. $0-\mathrm{X}-236$.

Kemperman, J. A., N. F. Lyon and S. Navratil. 1976. Incidence and volume of defect in second growth aspen stands in northern Ontario. Ont. Min. Natur. Resourc., For. Res. Rep. 102.

Kemperman, J. A., S. Navratil and J. T. Basham. 1978. Preliminary assessment of defect variation among aspen clones in northern Ontario. Ont. Min. Natur. Resourc. For. Res. Rep. No. 104.

Maini, J. S., and K. W. Horton. 1966. Reproductive response of Populus and associated Pteridium to cutting, burning and scarification. Can. Dep. For. Rural Devel., For. Br. Dep. Pub. No. 1155.

Sandberg, Dixon. 1951. The regeneration of quaking aspen by root suckering. M.F. Thesis, Univ. Minn.

Zehngraff, P. J. 1946a. Season of cutting affects aspen sprouting. USDA For. Serv., Lake States For. Exp. Sta. Tech. Notes No. 250.

Zehngraff, Paul J. 1946b. How to improve aspen suckering following summer logging. USDA For. Serv., Lake States For. Exp. Sta. Tech. Notes No. 251.

Zillgitt, W. M. 1951. Disking to increase stocking in aspen stands. USDA For. Serv., Lake States For. Exp. Sta. Tech. Notes No. 357. 


\section{Hydrology Working Group}

The hydrology working group is undertaking an assessment of the status of forest hydrology in Canada and would like all members of the C.I.F. to have the opportunity to provide input. Forest hydrology covers all aspects of land-use hydrology in forested areas pertaining to harvesting, road building and site preparation practice impacts on an interactions with water, including effects on streams and fisheries resources. We are interested in identifying problems and priorities on a regional basis, and determining the perception of the need for forest hydrology information and the extent to which government agencies and industry are concerned about and doing something about forest hydrology related problems. We would like to receive any ideas and opinions members may have on these issues. If you have something to say, jot down your comments right now while the thought is fresh in your mind. Send replies To:

\section{Dr. E.D. Hetherington, \\ Pacific Forest Research Centre, 506 West Burnside Road, Victoria, B.C. B8Z $1 \mathrm{M} 5$}

\section{Forecasting Forest Stand Dynamics Workshop}

On June 24th and 25th a National forestry workshop was held at Lakehead University. The workshop was entitled Forecasting Forest Stand Dynamics and it was attended by about 150 professional foresters from all over North America.

The traditional source of forest growth and yield information has been yield tables. Yield tables have been adequate for forest management purposes in the past because growth greatly exceeded demand and management was not very intensive. However, as the demand for wood has increased and as mixed species, second-growth stands, plantations and managed stands have become more common, yield tables have become more and more inadequate as a source of management information.

During the last 20 years alternatives to yield tables have been developed. They are mathematical models which predict the magnitude of forest growth in terms of existing forest conditions. These models are very flexible and can be used by forest managers to simulate the short- and longterm effects of alternative management plans on future forest inventories. The mathematics used in these models are the same as are used in the subject of dynamics in physics and engineering. Consequently, forest growth and yield analysis and forecasting has become a highly specialized, technical subject. Forest managers who have been out of school for even a few years soon find that they are out of touch with the current state of the art.
The purpose of the Forecasting Forest Stand Dynamics Workshop was to review recent theoretical developments and practical applications in this important field. The keynote address was given by Dr. J. Harry G. Smith, Professor of Forest Management, University of British Columbia and President of the Canadian Institute of Forestry. The capstone paper, entitled Forest Management Opportunities for the Future, was given by Dr. Jerome Clutter, Union Camp Professor of Forest Resources, University of Georgia. Dr. Clutter's work in the early 1960's started a revolution in growth and yield forecasting and he is one of the leading authorities in the field today. The other speakers included forest managers, forest scientists and forestry educators from throughout North America.

A panel discussion of provincial applications of forest growth and yield forecasting was moderated by Mr. Ken Armson, Ontario Ministry of Natural Resources. Panelists were Mr. W. Clifford, New Brunswick Department of Natural Resources; Mr. G. Frey, Saskatchewan Department of Tourism and Renewable Resources; Mr. J. C. Mercier, Quebec Ministere des Terres et Forets; Dr. J. Osborn, Ontario Ministry of Natural Resources and Dr. R. Quenet, British Columbia Ministry of Forests.

Applications in Canadian forest industry were discussed by Mr. L. Letourneau, Canadian International Paper Company and Dr. D. Reimer, Mac Millan Bloedel Ltd. Applications by the Canadian Forestry Service were discussed by Dr. R. A Fisher, Maritimes Forest Research Centre; Dr. T. Hall, formerly of the Pacific Forest Research Centre and Dr. C. H. Ung, Centre de Recherches Forestières des Laurentides.

In addition to the two days of technical sessions, three social events were held during the workshop. On Monday evening, June 23rd, an ice breaker was held in the Faculty Lounge at Lakehead University. This event was sponsored by Abitibi-Price Limited. On Tuesday evening, the delegates took a two-hour tour of Thunder Bay Harbour aboard the M. $\mathrm{V}$. Welcomeship and then attended a banquet at the University. Mr. Wes McNutt of Wm. Milne and Company Ltd., North Bay Ontario was the after-dinner speaker. Wine for the banquet was provided by K. B. M. Forestry Consultants of Thunder Bay.

The Workshop was sponsored jointly by the Lakehead University School of Forestry and the Biometrics Working Group of the Canadian Institute of Forestry. The principal organizers were Professors Kenneth Brown, Richard Clarke and Don Richardson, Lakehead University School of Forestry and Professor Steve Titus, University of Alberta.

Workshop proceedings will be published in the fall. To reserve a copy, write Dr. Kenneth M. Brown, School of Forestry, Lakehead University, Thunder Bay, Ontario P7B 5E1.

\section{New members/ Nouveaux Membres}

\section{Active/Actifs}

L. E. Birch

R. C. Boivin

W. H. Carmean

M. L. Della Rossa

J. P. Demaerschalk

B. M. Geisler

Laura W. Ives

H. W. A. Janning

T. G. Jeanes

R. E. Keen

A. Lovas

B. D. K. Hatch

T. G. McCarthy

B. T. McDonald
D. W. McFarlane

R. L. Mulaire

C. Roadhouse

A. A. Rotherham

J. F. Shaw

J. W. Stalker

E. R. Swanson

J. B. Zak

Affiliate/Affiliés

D. R. Bennett

B. W. Duquette

Student/Étudiant

B. Beard

B. D. Gilfillan

Jeff Henricks
Jane E. Mitchell

A. C. Treadaway

\begin{tabular}{|c|c|}
\hline \multicolumn{2}{|l|}{ Current CIF Membership } \\
\hline Honorary .... & 2 \\
\hline Fellow .... & 26 \\
\hline Active ..... & 1944 \\
\hline Affiliate ... & 93 \\
\hline Student .......... & 302 \\
\hline Retired ...... & 188 \\
\hline Temporarily Lost . ........... & 88 \\
\hline Tota & 2643 \\
\hline
\end{tabular}




\section{Research News and Views/Nouvelles et Points de Vue sur la Recherche}

The National Research Priorities Committee continues its 1980 survey of Canadian organizations actively engaged in forestry research. Reports 1 to 9 have been published in earlier columns and Reports 10 to 13 are presented in this issue. A special report by J. H. Cayford on Management of Forestry Research is also included in this column.

\section{Report Number 10: University forestry research in Now Brunswick and Nova Scotia.}

1- Faculty of Forestry, University of New Brunswick, from notes prepared by J. W. Ker, Dean.

Fields of interest. Forest soils, forest ecology, hydrometeorology and meteorology, outdoor recreation, forest ecology, forest wild life, forest management, forest. soils, tree biology, wood science, forest harvesting.

Funding. During 1979-1980, R \& D funding was received from the following agencies: 1) University of New Brunswick, 2) N.B. Department of Natural Resources, 3) DREE, 4) Canadian Forestry Service, 5) NSERC, 6) Forest Protection Limited, 7) Recreation Canada, 8) Parks Canada 9) Union of N.B. Indians, 10) Forest companies, 11) N.B. Energy Secretariat, 12) U.S. Forest Service, and some others.

Mailing list. Publications and informations can be obtained by contacting principal investigators.

Address: University of New Brunswick

Faculty of Forestry

P.O. Box 4400

Frederiction, N.B.

E3B 5A3

2- Fire Science Centre, University of New Brunswick, prepared by R. W. Wein, Director.

Objectives. To conduct research and to train Masters and $\mathrm{Ph}$.D. graduate students in the fields of fire ecology, fire suppression, prescribed burning and energy conservation and utilization.

Fields of interest. Research is conducted at the University of New Brunswick Fire Science Centre in Fredericton and primarily at the Acadian Forest Fire Science Area, located $20 \mathrm{~km}$ from Fredericton.

Funding. Main sources of funding are the Natural Sciences and Engineering Research Council of Canada, and other governmental bodies who provide grants and/or contracts.

Address: Director,

Fire Science Centre

University of New Brunswick

P.O. Box 4400

Fredericton, N.B.

E3B 5 A3

3- Department of Biology, University of New Brunswick, prepared by D. M. Keppie, Asst. Professor.

Objectives. Research/teaching.

Fields of interest. Neurophysiology-related to spruce budworm pheromones.

Address: Department of Biology

University of New Brunswick

Post Office Box 4400

Fredericton, N.B.

E3B 5 A3
4- Department of Biology, Dalhousie University, Halifax, N.S., prepared by B. Freedman, Asst. Professor.

Fields of interest. The major programme concerns the impact of harvesting forests on nutrient removal from poor forest sites. The field work is being done in Central Nova Scotia, in a wide variety of forest stands. Other research includes studies of the impacts of smelters on forests, studies of tree mortality due to beech canker, and several socioeconomic studies related to the use of forests. The latter are particularly concentrating on the hardwood resource of the province, which is currently underutilized, and its potential for use as a soft energy source, particularly for home heating. Other studies to be initiated in the near future include research on the impact of acidic precipitation on the fertility of forest soils.

Funding. The ENFOR programme of the Dept. of the Environment.

\section{Address: Dr. B. Freedman Department of Biology \\ Dalhousie University \\ Halifax, N.S. \\ $\mathrm{B} 3 \mathrm{H} 4 \mathrm{~J} 1$}

\section{Gilbert Paillé}

Member, Research Priorities Committee

\section{Report Number 11: Provincial forestry research in Ontario.}

1- Ontario Centre for Remote Sensing, prepared by V. Zsilinzky, Assoc. Director.

Objectives. To investigate and carry out applied research in remote sensing and to inform users of remote sensing of the newest technology available.

Fields of interest. The Centre has carried out and is at the present time involved with many forestry-related areas of applied research.

The data used for our forestry-related projects can be grouped into two categories:

1) Airborne Remotely-sensed Data

2) Satellite Data

The airborne data has been used for:

Fomes annosus

Spruce budworm

Large-scale aerial sampling

Forest regeneration success survey

Satellite data have been used for:

Mapping of forest fires and cutover areas

Productive forest inventory above latitude $52^{\circ} \mathrm{N}$

Forest regeneration success survey

Forest fuel mapping

Selective forest typing

Computer-analyzed satellite data were used for the latter four projects.

Thermal remote sensing has been applied in forestry to examine frost pocket detection within cutover areas and will be used further to detect the condition of the forest and to classify different forest types.

Funding. Ministry of Natural Resources. 
Address: Ontario Centre for Remote Sensing 3rd Floor, 880 Bay Street

Toronto, Ontario M5S 1 Z8

2- Ministry of the Environment, prepared by Dr. S. N. Linzon, supervisor.

Objectives. The objectives are to determine the effects of pollution on forests for industrial abatement purposes. Also, research results help in the formulation of air quality criteria and standards for the protection of forestry.

Fields of interest. In addition to studying pollutants of all types including sulphur dioxide, fluoride, ozone, ammonia, chlorine, hydrogen chloride, hydrogen sulphide, boron, cement dust, soot and metals, there is a strong interest in the terrestrial effects of acidic precipitation.

Funding. The source of funding is the Ontario Government.

Address: Forestry research is being done by the Ministry of the Environment in Ontario with offices and laboratories located in Toronto, Sudbury and Thunder Bay.

\section{Ministry of the Environment \\ Air Resources Branch \\ 880 Bay St., Suite 347 \\ Toronto, Ontario \\ M5S 1 Z8}

3- Ontario Hydro, prepared by the Manager, Transmission Environment.

Objectives. The main objective of this research is to determine the most effective control of vegetation that is incompatible with transmission lines, i.e, fast-growing deciduous species.

Fields of interest. $\mathrm{OH}$ is actively involved in the following research:

1. Testing the efficacy of various herbicides and application systems.

2. Evaluating plant response to growth regulators.

Funding. The source of funding for this research is in-house budgeted funds.

Address: Mr. R. A. McPhail

Ontario Hydro

700 University Av.

Toronto, Ontario

M5G 1X6

4- Ontario Research Foundation, prepared by Dr. S. G. Reid, Director, Dept. of Applied Chemistry.

Objectives. We provide research and technical services to industrial and government clients on a contract basis.

Fields of interest. ORF has many fields of interest, and service to the forest industry and to forestry consultants is one of these. Major areas are:

- Pulping studies on temperate and tropical tree species.

- Field and lab studies of overall forest utilization.

- Supply and demand for wooden poles in Canada.

- Development of planting tubes and containers.

- Fire retardant plywood.

- Utilization of wood species for particle board production.

- Modification of pulping processes to give increased yield.

Funding. Our main source of funding in contract work.

Address: ORF does forestry research at its lab in Sheridan Park, Mississauga, Ontario.
Ontario Research Foundation

Sheridan Park Research Community

Mississauga, Ontario

L5K 1 B3

Gilbert Paillé
Member, Research Priorities Committee

\section{Report Number 12: University forestry research in Ontario.}

1- University of Guelph Arboterum, prepared by E. Jorgensen, Arboretum Director.

Objectives. The Arboretum activities are entirely related to collection of plant materials at the present time. However, we hope that our native shrub and tree collection one day will supply a basis for a research program in forest genetics.

Fields of interest. The Arboretum work of interest to forestry and which may be interpreted as research, deals in trials with, and testing of, exotic tree species which have a possible potential for utilization within forestry and this is naturally one of the objectives of the Arboretum.

Funding. Sources of funding are the University of Guelph plus various private sources (Alumni, Service Clubs, etc.). For 1980/81, we have received a major development grant from the Ontario Ministry of Natural Resources, for the purpose of collecting and preserving genotypes of certain rare and endangered native trees and shrubs, as well as for other forestry related collections (Gene Bank and Commercial Trees).

Address: Erik Jorgensen, RPF

Arboretum Director

University of Guelph

Guelph, Ontario

N1G 2W1

2- Ontario Institute of Pedology, prepared by R. K. Jones, Forest Ecologist.

Objectives. The Ontario Institute of Pedology is a coordinating agency established to undertake soil resource inventories and research on soil genesis, morphology, classification, characterization, mapping and interpretation of the soils of Ontario. At present, the cooperating agencies in the Institute are the University of Guelph, through the Department of Land Resource Science; Agriculture Canada, through the Land Resource Research Institute, and the Ontario Ministry of Agriculture and Food, through the Food Land Development Branch. The "Institute" is based at the University of Guelph, Guelph, Ontario.

The Institute of Pedology carries on the important work previously conducted by the Ontario Soil Survey, however, with somewhat broadened objectives which includes the following.

1. To maintain a continuous and coordinated soil survey program in Ontario to provide the soil resource data necessary for making land use decision.

2. To provide basic research information on soil genesis, classification and mapping for improving existing knowledge, inventory techniques, soil correlation activities and land use interpretations.

3. To develop and quantify land evaluation techniques; to asses the suitability of land for man's use in agriculture, forestry, recreation, rural planning and other related uses in cooperation with others.

4. To compile, interpret and publish in a systematic manner the information obtained from soil resource inventories and associated research studies in the form of soil reports, maps and other publications. 
5. To provide practical field training for individuals requiring an increased knowledge of soil survey and mapping.

6 . To respond to requests for assistance and/or cooperation from other institutions concerned with pedological data.

Fields of interest. The OIP is, or will be (in the coming field season) involved in for forestry related programs.

\section{Forest Ecosystem Classification Program}

The Forest Ecosystem Classification program (FEC) is a cooperative research and development study involving five agencies: the Northern Region and Ontario Forest Research Centre, Ontario Ministry of Natural Resources; Great Lakes Forest Research Centre, Canadian Forestry Service; Ontario Institute of Pedology, Land Resource Research Institute, Agriculture Canada; and the Lands Directorate, Ontario Region, Environment Canada. With the support of and as a service to the Northern Region, the program has three major objectives for the Site Region 3E/Clay Belt area:

1) to develop an ecological classification of forest ecosystems (both disturbed and undisturbed) with an emphasis on the commercial forest;

2) to provide an initial interpretation and evaluation of the ecosystem types for forest (land) management purposes; and

3 ) to develop practical aids to identifying, and recognizing and mapping the ecosystem types both on the ground and on large scale aerial photography.

\section{Soil Interpretations for Forestry}

In recent years, soil survey information is being used and requested by an increasing number of land resource managers; well beyond the earlier agricultural uses of such inventory maps and data. In the area of forestry, the OIP has recently initiated soil interpretations for forestry program.

The broad objectives of this program are:

1) to make foresters more aware of the use and availability of soils information; and

2) to make the Institute's soil survey staff and researchers more familiar with foresters' needs with respect to soil interpretations.

The FEC study represents one aspect of this work in Northern Ontario. The results of this study will probably be presented in a Ontario Ministry of Natural Resources publication and as an interpretive section in the soil report for the northern Clay Belt soil surveys.

In Southern Ontario an interpretive study is beginning this spring for two county soil surveys that are near their completion in South-Central Ontario. The results of this study will be presented in these soil survey reports and possibly in a separate Ministry publication. With the assistance of Ministry staff, the objectives of this program are to:

1) determine the kinds of soil interpretations required;

2) determine the criteria necessary to make the interpretations;

3) develop a methodology to apply these criteria; and;

4) develop an approach to presenting the interpretations.

\section{Predictive Soil Mapping for Forest Management in Northern Ontario}

The time that elapses between the initiation of a soil survey and the publication of the final report is of necessity considerable. This time period of course increases markedly as the scale of mapping increases. The accumulation of soil inventory information for making forest management decisions is therefore slow. Considerable areas in Northern On- tario will not be surveyed for many years, even though soil information is required now for the planning of long-term forest management.

In the past year three soil survey map sheets at scales of $1: 50,000$ and $1: 250,000$ have been published for the Kapuskasing, Timmins and Cochrane areas. These surveys were produced by conventional soil survey methods. It is proposed to use existing land resource information such as bedrock geology maps, quaternary geology maps, Ontario Land Inventory land classification maps, Landsat imagery and Forest Stand Maps, to investigate the control on soil distribution on the published maps. Using the relationships established, a predictive soil map for the Foleyet and Chapleau areas will be produced. Field transects and an in tensive soil sampling program will aid in the testing of the predictive map. By refining predictive soil boundaries by field observation, it is hoped to produce a soil map of the Foleyet and Chapleau areas at a scale of $1: 250,000$ within a two-year period.

The predictive soil map will contain information, in an expanded legend format, describing soil texture, soil depth, soil moisture regime soil drainage, soil $\mathrm{pH}$ and landform or topography. The soils will also be classified at the subgroup level using the Canadian System of Soil Classification in order to tie in with the Ontario Institute of Pedology soil survey program.

\section{Seedling Germination and Forest Humus Forms - (Proposed)}

Forest humus is that proportion of the soil which acts as a functional interface between the forest vegetation and the underlying mineral or organic material. Forest humus forms vary with changes in forest cover and understorey vegetation (forest succession stage), soil flora and fauna, disturbances to the site, and the physiographic character of the site (climate, soil texture, structure, drainage/moisture regime, topographic position, etc.). In other words, the forest humus form can often be a key feature in identifying and characterizing the site condition of a forest ecosystem. In Boreal forests the forest humus is often the predominant substrate for seedling germination.

A number of distinct morphological forms are recognized and systems for their classification have been developed (Bernier, 1968). There is not, however, an adequate understanding of the relationship between these various humus forms and their ability to provide suitable substrates for seedling germination. It is proposed therefore to investigate a number of aspects of forest humus that relate to seedling germination. Amongst these will be their nutrient supplying capacity (e.g. K, Ca, Mg, etc.), and their contents of phenolic acids as allelopathic agents in seedling germination. The investigation would attempt to study the complete range of humus forms stratified by various forest types and physiographic conditions in the Boreal forest and relate these findings to seedling regeneration performance.

Funding. The FEC program is funded primarily with a DREE agreement and partially by the three cooperating agencies (OMNR, CDA and DOE). At the moment the SIF program is funded by the OIP. Funding for the PSM study is through the recent Canada-Ontario DREE agreement for forest management. The study on forest humus is presently under review for funding by the Ministry of Natural Resources.

Address: Dr. K. M. King, Director Ontario Institute of Pedology

University of Guelph

Guelph, Ontario

N1G 2W1

Gilbert Paillé

Member, Research Priorities Committee 
Report Number 13: Industrial Forestry Research in Eastern Woodlands

1- ABITIBI-PRICE, prepared by W. J. Johnston, vicepresident Woodlands.

\section{Objectives, fields of interest, contact.}

- 147 growth, and 159 reproduction, plots were established in the late 1940's and 1950's and up to three remeasurements have been made since establishment. For detail contact Mr. F. N. Robinson, Abitibi-Price Inc., Sault Ste. Marie, Ontario.

- hybrid poplar plantation: three acres planted in 1979 on Company freehold lots at Thunder Bay, Ontario. This is a co-operative project with Dr. L. Zuffa of the OMNR at Maple, Ontario. The objective is to determine the best of the several crosses developed for trial in northwestern Ontario - climatic conditions. Company contact is Mr. S. C. Howe, Lakehead Woodlands, Thunder Bay, Ontario.

- a woodlands laboratory was established by the Company in 1950 to determine whether cut-over areas could be regenerated naturally through modifications of cutting patterns. In June 1974 the area (16,000 acres) was granted for a 10-year period to the Lakehead University to carry out forestry research, instructional purposes, and continuation of certain experiments. It has been renamed "The Abitibi-Lakehead University Centre for Forest Resource Studies". Contact for information is with the Chairman of the School of Forestry at Lakehead University.

Address: Abitibi-Price Inc.

Toronto-Dominion Centre

Toronto, Canada

M5K $1 \mathrm{~B} 3$

2- La COMPAGNIE INTERNATIONALE DE PAPIER DU CANADA, préparé par G. Paillé, directeur de la recherche forestière.

Objectifs. Les activités de recherche appliquée et de développement forestier ont pour but premier de permettre ou de faciliter l'aménagement intensif de toutes les pro. priétés forestières de la Compagnie et des forêts publiques qui sont utilisées pour l'approvisionnement de ses usines.

Champs d'activité. Des études sont conduites par le personnel de la Compagnie seul ou en collaboration avec les organismes de recherche reconnus dans les principaux champs d'activité suivants:

a) amélioration des arbres forestiers, surtout le pin gris, l'épinette et le mélèze;

b) régénération naturelle et artificielle des parterres de coupe;

c) sylviculture des forêts résineuses (sapin, épinette, pin) et feuillues;

d) inventaires d'aménagement et d'exploitation;

e) diverses autres activités d'aménagement forestier (classification écologique des peuplements, influence des exploitations sur la qualité de l'eau, protection des forêts contre la tordeuse).

Financement. La Compagnie défraye le coût des travaux conduits par son personnel; le coût des travaux faits en collaboration est défrayé par ceux qui en sont responsables.

Adresse. Les activités de recherche et de développement forestiers sont conduites dans chacune des divisions forestières de la Compagnie dont les bureaux sont situés à Dalhousie au Nouveau-Brunswick, à Maniwaki, à La Tuque et a Grenville au Québec. Toute demande de renseignements peut être adressée au siège social à l'adresse suivante:

Directeur de la recherche forestière

Exploitation forestière

Compagnie Internationale de Papier du Canada

Édifice Sun Life

Montréal, Québec

H3B 2X1

3- CONSOLIDATED-BATHURST INC., prepared by J. G. MacLeod, vice-president Woodlands.

Objectives. For many years Consolidated-Bathurst Inc. has engaged in forestry research independently, and in cooperation with other research agencies, mainly governmental.

Recently its efforts have been channelled almost exclusively into joint undertakings with these agencies although it continues to do some small scale work on its own.

Much of the research in which we have been or are engaged is in response to problems connected with the application of intensive forestry practices to plantations.

We are involved in regeneration silviculture in the natural forest in an effort to increase the fund of knowledge concerning the regeneration of specific species and to evolve appropriate techniques.

Fields of interest. Inasmuch as the Company has its own planting programme and carries out regeneration work on a contractual basis from time to time, our interest encompass the following fields:

a) Establishment and tending of stands.

b) Tree improvement and breeding.

c) Fertilization.

d) Tree diseases.

Funding. Company funds cost of its men, material and equipment, except on contractual work.

Address. The result of cooperative research projects are usually disseminated through reports published by:

a) Centre de Recherches Forestières des Laurentides P.O. Box 3800

Ste. Foy, Quebec

b) Gouvernement du Québec

Ministère de l'Énergie et des Ressources

Service de la Recherche

Québec, Québec,

Results not thus reported are covered by internal reports which could be made available on request to ConsolidatedBathurst Inc., Grand'Mère, Québec G9T 5L2.

4- FRASER INC., prepared by G. K. Bowser, Manager of Forest Development \& Planning.

Objectives. Fraser Woodlands has a number of Research and Development projects currently underway. Please note that none-are strictly "pure" Research.

The basic objectives could be stated as follows

a) To increase our knowledge of the forest we now have and its behavior so that reasonable predictions can be made as to its future development.

b) To develop silvicultural techniques suited to our species, soils and climate in order to improve the quality and productivity of our future forests.

Fields of interest. The specific fields of interest are:

a) To predict development patterns on natural stands.

b) To predict the pattern of development of natural regeneration after harvesting. 
c) To develop artificial regeneration methods and/or regeneration aids other than planting seedlings.

d) To improve the genetic quality of seedlings for use in large scale plantings.

e) To develop the art of using herbicides for competition control with minimum side effects. This includes, of course, testing the performance of various herbcides.

\section{Funding.}

a) Indirect - Through claiming the cost of projects as a Tax Credit.

b) Direct -

(i) Through the STEPEX program of the Department of Manpower in cooperation with the University of New Brunswick.

(ii) Our own financing.

Address: G. K. Bowser

Manager of Forest Development \& Planning

Fraser Inc.

Edmunston, N.B.

E3V 159

5- KIMBERLEY-CLARK OF CANADA LTD., prepared by M. A. Opper, director forest management.

Objectives. The objectives of our research program are to provide genetically improved black and white spruce seed for use in the Kimberley-Clark forest nursery.

Fields of interest. The fields of interest in this regard are:

1. Plus tree selection for use in a grafted clonal seed orchard

2. To perform controlled crosses

3. To conduct progeny tests of both half sibs and full sibs to select superior clones.

Address: Kimberley-Clark of Canada Ltd.

Longlac, Ontario

CANADA

POT $2 A 0$

6- LA COMPAGNIE PRICE LTÉE, préparé par L. Morais, chef forestier.

Objectifs. Les objectifs des études de régénération après coupe faites par notre Service Forestier sont de connaître la quantité et la qualité de régénération naturelle de résineux après les différents systèmes d'exploitation. Des placeséchantillons sont établies et revisées à tous les 3 à 5 ans dans nos concessions du Saguenay-Lac St-Jean et de Rimouski-Métis.

Financement. Ces études sont financées entièrement par notre Compagnie.

Publications. Aucune publication n'a encore été faite de ces travaux à long terme qui sont encore en progrès.

Adresse: La Compagnie Price Ltée

65 , rue Sainte-Anne

Québec

G1R 3X5

7- PRICE (NFLD.) PULP \& PAPER LTD., prepared by E. Burton, Chief Forester.

Objectives. Forestry research is being done in Central Newfoundland, primarily in the Exploits River watershed.

The research objectives of the silvicultural arm of this Company are:

a) through pre-commercial thinning and fertilization experiments, to determine optimal yield conditions;

b) through reforestation experiments to determine methods for reclaiming roads and landings; c) through reforestation experiments, to determine methods for reforesting clearcut hardwood sites to softwoods:

d) through monitoring currently budworm-killed stands, to determine a method to predict reforestation requirements of stands that may be killed in the future;

e) through harvesting and reforestation experiments on mixed-species sites, to determine the costs and practicability of integrated logging in a Newfoundland situation.

Fields of interest. The specific fields of interest of the silviculture arm of this Company are silvicultural research and applied silviculture.

Funding. The main sources of funding are the federal Energy from the Forest (ENFOR) program, the federalprovincial Forest Economic Stimulation Program (FESP), and the Company.

Address: E. Burton, Chief Forester Price Pulp and Paper Ltd. P.O. Box 500

Grand Falls, Newfoundland A2A 2 K1

8- Spruce Falls Power and Paper Company Ltd., prepared by V. Sleep, Superintendent of Forestry Services.

Objectives. The objective is to improve our knowledge of stand dynamics in order to make better forest management decisions.

Fields of interest. A small research program is being continued on the company limits at Kapuskasing, Ontario.

We have over 200 permanent sample plots in virgin stands, cutover, burned areas which are remeasured every 5 to 10 years, primarily to determine growth and yield data.

Funding. Funding is entirely by Spruce Falls.

Address: Spruce Falls Power and Paper Company, Limited P.O. Box 100

Kapuskasing, Ontario

P5N 2 Y2

Gilbert Paillé

Member, Research Priorities Committee

\section{Management of Forestry Research Study Tour}

\section{J. H. Cayford'}

In September 1979 the Management of Forestry Research Subject Group of the International Union of Forestry Research Organizations (IUFRO) held a study tour in Canada and the United States. Insofar as I am aware, this is the only organization devoted solely to the problem of managing research.

About 20 delegates from six countries and representing four continents (North America, Asia, Africa and Europe) participated in the tour which visited federal, provincial, university and industrial forest research agencies in the two countries. In Canada, visits were made to the Great Lakes Forest Research Centre and the Forest Pest Management Institute of the Canadian Forestry Service, to the Ontario Ministry of Natural Resources' Forest Research Centre, to the Faculty of Forestry, University of Toronto, and to the Abitibi Research Centre and the Ontario Research Foundation at the Sheridan Park Research Community. In the United States visits were made to the North Central Forest Research Station and the Forest Products Laboratory of the 
U.S. Forest Service, to the Universities of Michigan and Wisconsin, and to the Institute of Paper Chemistry.

The study tour provided an excellent opportunity for managers of forestry research programs to discuss problems of mutual interest, and it was interesting to find that many of the issues and problems are worldwide. The most important issues seem to be those of research planning, determination of work programs, and establishment of priorities. There are no pat answers, and indeed the research manager must exercise a considerable amount of judgement. These topics were discussed at each establishment visited and it appeared as if the U.S. Forest Products Laboratory had given them most consideration. The Director outlined the following criteria used for setting research priorities - broad objectives of government, public interest, benefit/cost ratio, likelihood of success, urgency, applicability, capabilities of Forest Service and co-operators, and duplication. Many factors were considered by FPL in determining program direction; factors considered included FPL mission and tradition, advice from government administration, advice from Chief of the Forest Service, external program review, program budget Resource Planning Act program and assessment, and research work unit descriptions.

Another concern was in evaluating research productivity and in evaluation of the performance of scientists. The U.S. Forest Service employs a peer system for scientist appraisal. Each scientist is evaluated every three years at which time grade level is determined. Within a grade, advancement is automatic and may be annually, biennially or triennially. On the other hand, at the Institute of Paper Chemistry, scientists are appraised annually by supervisors with a minimum of documentation. There was a general consensus that scientists must remain current and up-to-date, and that managers have a role in this matter.
All establishments were concerned about program restraint and undue bureaucratic influence on science. However, nowhere did there seem to be as much concern with the future as there is within the Canadian Forestry Service. Clearly, the U.S. government accepts forestry research as an on-going program. However, it was noted that there was too little support in the U.S. for research in the basic sciences.

The three universities were all extremely concerned about the shortage of research funding. However, it was noted that the U.S. Forest Service is far more involved in cooperative university research than is the Canadian Forestry Service. This is an area that should be looked at carefully whenever one is looking at possibilities for expanded forest research programs in Canada. In my view, co-operative university research would be more fruitful than the current Canadian policy aimed at contracting out of forestry research to Canadian industry.

Other topics that were widely discussed included quality of research and suitable mechanisms to ensure quality control and age-class distribution of forest scientists. Age-class structure was of particular concern to the two federal forest services where recruiting has been restricted over the past decade.

Many members of the Canadian Institute of Forestry have an obvious interest in forest research, either as researchers themselves or as forest managers interested in using research results. Forest managers have a responsibility to keep themselves informed of current research activities through the literature, by personal contact with researchers, and by visiting forest research agencies. They also have a responsibility to make their research needs known to research managers and scientists.

\footnotetext{
${ }^{1}$ Member, Research Priorities Committee
}

\section{CIF and Imperial Life - a 20-year association}

The Canadian Institute of Forestry and The Imperial Life Assurance Company of Canada have been together for 20 years, providing life insurance protection for CIF members. Imperial Life is proud of the association and of the special features of the CIF life insurance plan:

- The maximum amount of insurance available is $\$ 100,000$ (up to age 50 ).

- We've kept the same low premium rates.

- Members' spouses and full-time employees of members may enroll in the plan.

- There's a $50 \%$ bonus payable on any claims arising during the period May 1, 1980 to April 30 , 1981 . This means that if, for example, you arrange $\$ 100,000$ of protection, $\$ 150,000$ would be payable at no extra cost during the 12-month period.

For more information about how you can take full advantage of this valuable life insurance plan, write to the Canadian Institute of Forestry, Box 5000, Macdonald College (Quebec) H9X 1C0. 


\section{PRESTOSEC - Current Discussion Topics for Members}

PRESTOSEC is the Newsletter of the CIF/IFC. it is issued only when there is news of general interest to the forestry community across Canada rather than being a periodical issued on a regular basis. It provides news and information only in brief and, therefore, does not duplicate material published in The Forestry Chronicle, but rather supplements, and in some cases complements such material. The main idea is to spread information rapidly across the country in between mailings of The Forestry Chronicle.

Currently, PRESTOSEC goes to Executive, Section Officers, Past Presidents, Committee and Working Group Chairmen and a selected group of other Associations. A number of Sections already include it in whole, or in part, in their Section Newsletter. It is hoped all Sections will do this soon.

Recently there has been a number of requests to send this newsletter to a) all members and/or b) to include it as a page in The Forestry Chronicle.

The answer to a) is aimple: - it would cost $\$ 5000-\$ 6000$ per year to do this whereas the current system only costs about $\$ 400 /$ year.

The answer to b) is slightly more complicated. The Forestry Chronicle is issued every two months and news to be included must be in the Editor's hands the month before publication. This means that an item of news describing something that happened on June 1 would miss the June issue of The Forestry Chronicle and would not appear until two and one-half months later in the August Chronicle. Also, it means there would be no communication of news or information between the issues of The Forestry Chronicle.

If the information from, or photocopies of, PRESTOSEC are sent out with the Section Newsletter, it will cost the Sections next to nothing in postage as it is usually only one page. If it is sent to centres of employment, it can be pinned on Notice Boards and reach a number of members and other people for very little cost.

PRESTOSEC is meant for just what is stated at the top of the page, "Current Discussion Topics for Members". If you have anything you want discussed or some information or news you think other members would be interested in, please let me know.

"PRESTOSEC" means a "Present to Sections". It also means "Fast and Dry". It is issued when news warrants so it may arrive often, or not for a month or two, as the occasion demands.

If you wish to receive it - ask your Section Chairman.

A. G. Racey

\section{To All Members of the CIF/IFC}

This is official notice (By-law 9.1.1) that the Annual General Meeting of the CIF/IFC will be held in the Chateau Laurier Hotel, Ottawa, Ontario, Monday, October 6 and Thursday, October 9, 1980, with President J. Harry G. Smith presiding.

\section{$50 \& 25$ years / 50 et 25 ans}

\section{Years/50 ans}

The cardinal points of any forest policy are protection and perpetuation; save what we have at any point of time from unnecessary waste and make provision for the future crop when or before, the present crop is converted to the needs of man. Whatever ideas I may bring to you this afternoon will be grouped around the two words protection and perpetuation and whatever I shall say will be said only in the spirit of helpfulness. As shareholders of our public domain we have laid ourselves open to very severe criticism through lack of interest, even of neglect, and the consequent failure in constructive planning and performance in the keeping of that domain in its best productive condition. However much we may deserve destructive criticism and being held up to pilloring on a public stock, such tactics really get us nowhere and they leave in their wake only discord and illfeeling - conditions not conducive to progress in any line of endeavour. Our forest situation both from the standpoint of protection and perpetuation is so critical at the present time, that it behoves every forward thinking and patriotic citizen to give it his very best thought and to transform that thought into constructive action. Otherwise, so intimately interwoven is the forest in its climatic influence, in its regulatory influence on water power, in the use of its products with our daily activities and daily needs that the wealth producing capacity and hence the prosperity of this beloved Dominion of ours will surely decline.

\section{D. Howe}

\section{Years/25 ans}

It is a well established fact that all native tree species of eastern Canada have invaded their present range since the last glaciation. In the strictest sense, none is native to
Canada, with the possible exception of some species that survived the last glaciation in Newfoundland and on the now submerged continental shelf (Halliday and Brown, 1943). Therefore, the genetic diversity of eastern Canadian trees represents but a fraction of the total possible genetic diversity within each species. Many gene combinations and new genes, not found in native Canadian materials, can be expected to be present within populations growing to the south of their ranges in Canada, and closer to their supposed refugia during the last glaciation. Three main such refugia have been postulated by various authors (Halliday and Brown, 1943; Hulten, 1937), namely the presently submerged continental shelf off the east coast and parts of Newfoundland, the unglaciated portions of the Allegheny and Appalachian Mountains and the unglaciated portion of the land mass to the west of these mountains.

Even if post-glacial changes in climate might have led to gene depauperation within tree populations of such refugia, there is every reason to believe that the existing materials are sufficiently different from their present Canadian counterparts to make possible a considerable enrichment in the present genetic diversity of the latter. Such genetic enrichment can help us to extend the climatic and edaphic ranges of valuable native tree species. It can make possible the synthesis of strains that are more diversified and plastic than the available native strains and thus help to build up natural resistance against possible depredations by insects and fungi. It can also build up ecological diversity within the species concerned and make it possible to create naturally perpetuating stands of a species on sites and in areas where it is not native or where it can only be reproduced by planting. It is also probable that some of the new gene combinations made possible by the introduction of new breeding materials may result in hybrid vigor, manifesting itself in increased growth and higher yields.

C. Heimburger and $M$. Holst 


\section{University News I Nouvelles des universités}

\section{University of New Brunswick}

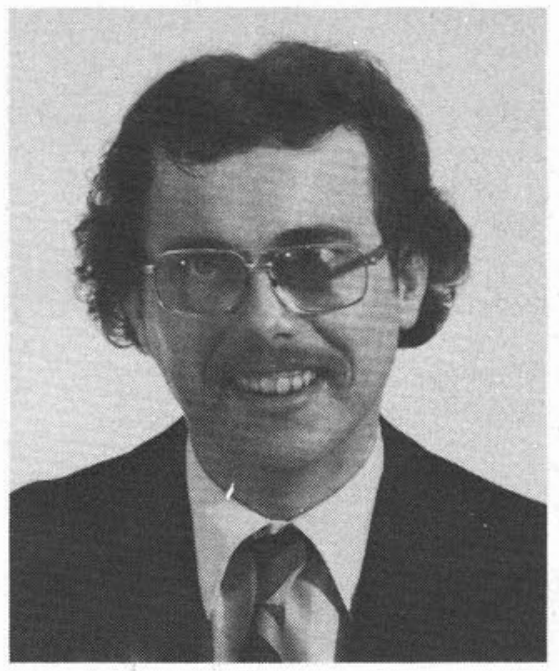

\section{UNB CIF Medal Winner}

Wietse Lense Meyer, the University of New Brunswick winner of the Canadian Institute of Forestry Medal, is the son of Mr. and Mrs. Lense Meyer of Fredericton, New Brunswick.

Mr. Meyer entered UNB's forestry program in September 1975 , and graduated from the Faculty of Forestry with the degree of Bachelor of Science in Forestry (B.Sc.F.) in May of 1980. High academic standing throughout his undergraduate years and extensive involvement in forest soils research qualified $\mathrm{Mr}$. Meyer for the award.

Mr. Meyer also holds a National Science and Engineering Research Council post-graduate scholarship and plans to do graduate work in forestry.

\section{Faculty Briefs}

Professor C. A. Short, Forest Engineering, spoke on "The Mechanics of Efficient, Convenient Wood Heating" at a meeting of the New Brunswick Teachers' Association Science Council at Mount Allison University in May.

Dr. M. H. Schneider, UNB wood scientist chaired a session on present and future developments in structural board manufacturing at the spring meeting of the Forest Products Research Society, Eastern Canadian Section, held in Moncton, NB, in mid-May. The meeting had a strong international flavour with speakers and attendees representing both North America and Europe.

Professor R. B. B. Dickison, forest hydrometeorologist, presented a paper at the June UNESCO symposium on "The Influence of Man on the Hydrological Regime" in Helsinki, Finland.

Professor T. C. Bjerkelund, Forest Engineering, left for Sweden in June to begin a six-month sabbatical. His project, in cooperation with the Department of Operational Efficiency, College of Forestry, Swedish University of Agricultural Sciences at Garpenberg, involves the examination and analysis of those tree-harvesting functions that have an effect on future stand establishment. Considered to be especially significant is the correlation of degree of processing carried out at the felling site with site preparation.

Professor E. J. Rickards, Forest Engineering, presented two papers in May: "The Major Unit of Activity: A Simplified Approach to Measuring and Controlling Indirect Labor" at the annual conference of the American Institute of Industrial Engineers in Atlanta, Georgia; and "Maintenance of Labor Efficiency in the Forest Industry" at the national meeting of the Logging Operations Group (Canadian Pulp \& Paper Association) in Toronto.

Dr. A. Dickson, Coordinator of Continuing Education in Forestry, "joined the uprising" in May when he addressed the annual meeting of the New Hampshire Timberland Owners Association. The theme of the meeting was "Revolution in the Woods"' and Dickson's topic was "Increased Productivity Through Effective Communications".

Dr. J. W. Ker was one of four Canadian forestry school deans to visit China during the month of July. The 17-day trip, arranged through diplomatic channels by Dr. V. J. Nordin of the University of Toronto, took the group to Peking, Harbin, Nanking and Canton to visit a Forest Research Council, a Forest Institute, a Forest products Industrial College, a Forest Science Research Station, a Forestry Bureau, timber processing plants, a nursery and botanical gardens.

\section{Professor Aids African University}

Professor N. L. Kissick, Forest Resources, has recently returned from a sabbatical spent at the University of Nairobi, Kenya, where he assisted in undergraduate teaching, giving courses in forest management and forest fire control. In addition, he was asked to develop a curriculum for the undergraduate program in resource management for the fledgling school.

The major problems in resource management in Kenya are an extremely high population growth, approaching $4 \%$ per annum, and a limited land base capable of producing food, wood and water. One need is to encourage cooperation in place of competition among land managers to ensure the optimal use of every acre of land in the years ahead. Another is to develop ways in which arid lands can be made to support the expanding population. The possibility that trees can contribute to a solution is an interesting and challenging project in which foresters can play an important role.

Accordingly land-use planning and "agro-forestry" must receive considerable attention in the curriculum that is developed for the forestry department at the University of Nairobi.

\section{Professor Publishes}

Co-author of the Canadian Pulp and Paper Association publication, A Guide for Evaluating Maintenance Organizations, is Professor E. J. Rickards, Forest Engineering.

The Guide is an ordered checklist of questions divided into these eight sections for ease of reference: Structure, Personnel, Supervision, Safety, Facilities, Programs, Cost and Policy. It is a series of reminders that permit examination of every important question that needs to be considered when 
creating, upgrading, or simply checking on a maintenance organization.

This 50-page booklet, available free from CPPA, is attractively illustrated with line drawings. According to the authors, it meets "a genuine need within the logging industry".

\section{Continuing Education in Forestry}

The score card for courses in May and June reads " 3 wins, 1 loss". The winners were: "Wood Identification and Wood Moisture Relationships for (Museum) Collections Care Personnel"' (two days, 18 participants representing Ontario, New Brunswick and Nova Scotia); "Basic Statistical Methods for Cruisers and Scalers" (four days, 16 participants representing Manitoba, Maine, New Brunswick, Newfoundland and Nova Scotia); "Lumber Kiln-Drying for Managers and Operators" (three days, 36 participants representing New Brunswick and Prince Edward Island).

The loser was: "Forest Regeneration by Planting" (insufficient enrollment).

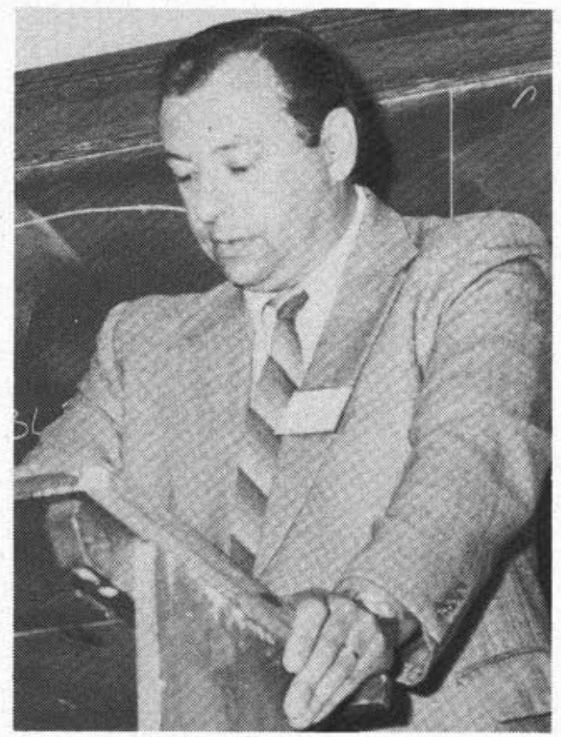

Wilfred Torunski, Chairman, Maritime Section, CIF, was one of key organizers of the UNB course on the kiln drying of lumber. His employer, NB Department of Commerce and Development cosponsored the event.

Prescribed Burning in New Brunswick - "Where Do We Go From Here?" is the title of the spring issue of UNB Forestry Focus (Vol. 5 No. 2). Written by Dr. A. J. Kayll, the forestry faculty's forest fire ecologist, the article outlines the current status of prescribed burning as a silvicultural management tool on crown Lands, and makes suggestions for enhancing the use of the Canadian Forest Fire Behaviour System in developing prescriptions for operational burns.

Extra copies of this issue are available free of charge as long as the supply lasts.

\section{Alex Dickson}

\section{Lakehead University}

\section{Graduation}

This year 44 students received their B.Sc.F. from Lakehead University. A large number of these graduates obtained jobs of Ontario. Technologist graduates numbered 54 this year. It is still difficult for them to obtain permanent employment in spite of the increasing concern for more forest management. There were, however, more seasonal jobs than could be filled this year.

\section{Awards to Students}

James Sutherland won the Canadian Institute of Forestry Gold Medal for being the best all-round student in scholarship, sports and citizenship.

Cynthia Fairlie was awarded the Commonwealth Forestry Book Prize for her scholarship and student led activities.

Lynn Pawson received the Ontario Professional Foresters Association Prize on the basis of her academic standing and professionalism.

Derrick N. Tirschmann was the most deserving student in the Wood Technology area, thus he received the Forest Products Research Society, Eastern Canada Section Award.

Peter Higgelke received the Kokums Scholarship for the best thesis on logging operations in North America.

The President's Awards, to graduating students who occupied positions of responsibility in student organizations and who by their activities and achievements have earned the gratitude of the University, were presented to Donna Ruth Burton and Lynn Carol Pawson.

For being the highest ranking graduate student in Degree Forestry, Geoffred Harold Cushon was presented the Dean Braun Medal. In the Forest Technology program, the Dean Braun Medal was presented to Vincent Thomas Keenan and Douglas Leslie Orr.

The above awards were all presented on May 31, 1980, at the Lakehead University Convocation. The Honorary Degree of Doctor of Engineering was conferred upon Benjamin Cowan, a former resident of Thunder Bay. Prior to his gaining renown in the consulting and engineering services for the Pulp and Paper Industry he spent several years on logging operations and cruising in northern Ontario and Quebec.

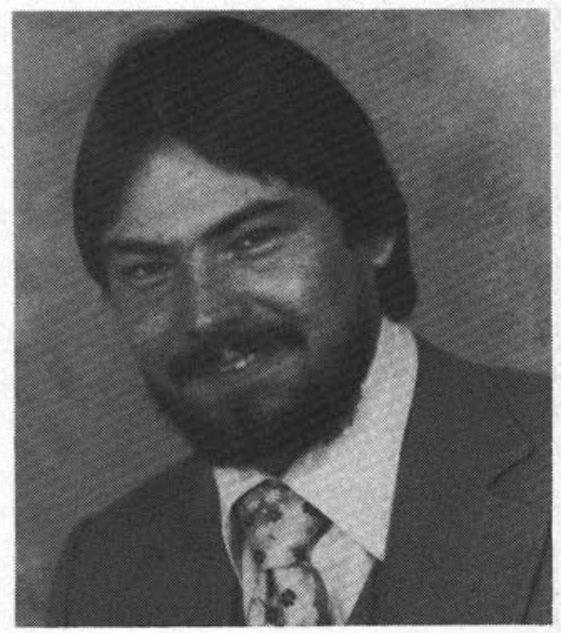

\section{LU CIF Medal Winner}

This year's recipient of the CIF gold medal from Lakehead University is James Sutherland, who came here from Manitoba.

Mr. Sutherland received this recognition on the basis of his academic standing and his active participation in various formal and less formal functions of the School of Forestry. His undergraduate thesis subject was on the economics of a pine plantation in northern Ontario. He obtained his practical experience during a number of summers in various parts of the country and is now in the process of applying his theoretical and practical knowledge achieved over four years in the forestry province par excellence. Among the snow-capped mountains of British Columbia he works for the B.C. Forest Service.

\section{Canadian Forestry Service Subvention Grant}

The $\$ 49,000.00$ allocated to Lakehead University by the Canadian Forestry Service will support the following activities this year: 
1. Graduate Student Bursaries (6)

2. Dr. W. Carmean - Site Index Curves for Forest Species in Ontario

3. Dr. K. M. Brown - Effect of Spacing and Fertilization on the Growth of Jack pine.

4. Prof. K. C. Yang - Complete Tree Study of Trembling Aspen

5. Prof. R. J. Day - Post-logging Succession and Vegetation Management with Herbicide in White Spruce Trembling Aspen Forest

6. Faculty - Automic Tree Measurement Device

7. Dr. H. G. Cumming - Effects of Logging on Caribou.

C. Benson

\section{University of Toronto}

\section{President James Ham, D. C.}

President James Ham is among 64 Canadians to be invested into the Order of Canada at a Government House ceremony this fall.

\section{Gold Medal Plaque to Martell and Bookbinder}

Professor David Martell of the Faculty of Forestry and Dr. James Bookbinder of the Faculty of Management Studies and the Toronto Transit Commission were awarded the Canadian Operational Research Society's Gold Medal Plaque. The award was for their paper titled, Timedependent queueing approach to helicopter allocation for forest fire initial-attack, which was judged the best paper by a member in the 1979 volume of the journal INFOR.

\section{Professor Howard Rapson Recelves Medal}

Professor Howard Rapson was awarded the Chemical Institute of Canada Medal for outstanding contributions in chemical engineering. During his career with the Canadian International Paper Company and the University of Toronto he has made many contributions to the science of wood pulp bleaching. His research has recently culminated in the first closed-cycle bleached-kraft pulp mill at the Great Lakes Paper Company, Thunder Bay.

\section{Now Appointment}

Mr. J. R. Pickering, B.Sc.F., M.Sc. (P1.) (Tor.) has been appointed to the Faculty as Assistant Professor. Mr. Pickering's responsibilities will include undergraduate teaching and research in Forest Management/Outdoor Recreation and related areas.

\section{Botany '80 Conference}

Professor Terence Carleton participated in the 1980 Canadian Botanical Association Conference and the IVth International Conference on Experimental and Evolutionary Biology at the University of British Columbia, Vancouver, in July.

\section{Spring Convocation}

Dr. A. B. B. Moore, Chancellor, conferred the degree of Bachelor of Science in Forestry on 61 graduates, and the Diploma in Resource Management on one graduate, at the Spring Convocation ceremony held June 11 . The graduates were presented to Dr. Moore by Professor V. G. Smith, Faculty of Forestry. Dean Vidar Nordin hosted a reception afterwards to honour the graduates, along with parents and friends, sponsored by the Forestry Alumni Association.

\section{Three Generations of Foresters}

Liza (née Smith) Minns 8T0 is a third generation forester. Her uncle is the late Dudley Avery 4T6 and her grandfather is the late Ben Avery, Yale '14. Mrs. Minns has also made history by being the first child of an academic staff member to graduate from the Faculty. Her father is Professor Victor Smith.

\section{Award Winners 1980}

Award winners in the graduating class of the Bachelor of Science in Forestry program included J. M. Fullerton (Canadian Institute of Forestry Medal), P. Roebbelen (Ontario Professional Foresters Association Prize), D. L. Booth (Commonwealth Forestry Bureau Book Prize), S. S. Chan and M. M. Lepper (Forest Products Research Society Eastern Canadian Section Wood Award).

Third Year winners were J. A. Kroetsch (T. W. Dwight Prize in Forest Mensuration), A. S. Lewis (F. K. Morrow Forestry Scholarship, and the Osmose-Pentox Scholarship), and P. S. Babor (The Weyerhaeuser Scholarship).

Second Year winners were W. C. Hewitt (Class of 5T2 Award) and P. S. Janas (Harold S. Edmonds Prize, Frank A. MacDougall Scholarship, Professor Arthur Stephen Michell Award in Forestry, and the M. R. Glavicic Award).

First Year Winners were S. D. Moore (Fred G. Jackson Award) and B. J. Naylor (Wallace A. Delahey Scholarship, and the Robert C. Hosie Prize in Dendrology).

\section{Class of 5T5 Forestry Reunion}

One of the Spring Reunion highlights for the class of 5T5 Forestry, returning to the campus after 25 years, was a tree planting ceremony. With the cooperation of the University's Grounds Department and aided by Dean Vidar Nordin and Associate Dean David Love, class members planted a sugar maple tree on the south slope of the Old Observatory knoll, immediately in front of Hart House. Class members, well used to the long-term planning inherent in forestry activities, look forward to enjoying the tree's shade during the Spring Reunion celebrating their second quarter-century in the year 2005. In addition to the all-Varsity reunion program, the festivities for the returning forestry alumni began with a wine and cheese party hosted by the Faculty of Forestry. Further events for 5T5 Forestry members included a picnic with members of classes 3T0 and 4TO at Doug Drysdale's Tree Farm.

Paul L. Aird 


\section{U. of T. CIF Medal Winner}

Mr. John Michael Fullerton, the winner of the 1980 Canadian Institute of Forestry Medal at the University of Toronto, Attended Jarvis Collegiate Institute in Toronto and the Maritime Forest Ranger School, Fredericton, before entering the Forestry program at the University of Toronto in September, 1976.

Mr. Fullerton maintained a high scholastic standing throughout his four undergraduate years, and in addition to the Canadian Institute of Forestry Medal he has been the recipient of the M. R. Glavicic Prize (based on the areas of tree morphology and wood identification) and the T. W. Dwight Prize in Forest Mensuration. In his final year he graduated with first honours and the degree of B.Sc.F was conferred June 11, 1980.

Mr. Fullerton was very active in student affairs and included in his accomplishments are: member of the Student Advisory Committee to the Dean, member of the Faculty's Undergraduate Curriculum Committee, and President of the Foresters' Club.

The CIF Medal is awarded to Mr. Fullerton in recognition of his excellent academic record and his active participation in student affairs.

\section{University of British Columbia}

\section{Festival of Forestry}

Dr. Oscar Sziklai was involved with organizing of the Festival of Forestry tour, the 25th since its inception in 1967. This year 21 participants travelled to the Queen Charlotte Islands, bringing to 505 the number who have been exposed through this program to the province's most important renewable resource, the forest, and the people associated with its management. The aim of the Festival of Forestry tours is to foster a better understanding of our forests on the provincial, national, and international levels in those who will be responsible for its future management.

\section{Faculty Appointments}

The following appointments have been made to the Faculty of Forestry, effective July 1, 1980. Dr. Peter H. Pearse, appointed as Professor, will be concerned with forest policy and economics. Dr. Pearse is moving to this faculty from the Department of Economics of the Faculty of Arts. He headed the Royal Commission on Forest Resources in British Columbia, the report of which was completed in 1976. Dr. Robert W. Kennedy, who was Visiting Professor with the faculty this past year, has been appointed Professor. Dr. Kennedy, formerly Director of the Western Forest Products Laboratory, will be involved with wood science and forest products. Dr. Karl Klinka has been appointed Adjunct Assistant Professor. Dr. Klinka is with the B.C. Forest Service, and one of his chief interests has been biogeoclimatic classification. His field of endeavour within the faculty will be forest ecology.

\section{Faculty Notes}

Professor Jack Walters has received a contract from the B.C. Forest Service to design and build an automatic treeplanting gun. The gun will be attached to an FMC skidder and will be operated by the skidder driver. The machine will plant upwards of 750 seedlings per hour. A similar machine is being constructed for Northwood Pulp and Timber Ltd. of Prince George.

Drs. Fred Bunnell, Harry Smith, and Gordon Weetman attended the IUFRO/MAB Conference on Research in Multiple Use of Forest Resources at Flagstaff, Arizona, May 18-26. Papers were presented by Dr. Smith (Costs and Benefits of
Multiple Use in British Columbia), and Dr. Weetman (Research Techniques for Multiple Use).

Dr. Peter Murtha presented a poster session on photo interpretation of ground-fire damage to trees at the 6th Canadian Remote Sensing Symposium in Halifax, May 21-23.

Dr. John McLean attended the Forest Pest Review Committee meeting in Williams Lake, B.C., June 4-5.

\section{Publication}

"Co-ordinated resource planning: room for improvement?' Rangelands, June, 1980 (in press), by R. M. Strang.

Douglas L. Golding

\section{Obituary/Nécrologie}

\section{John O. Wilson - 1881-1980}

In June 1980, the forestry profession lost one of its most eminent members.

J. O. Wilson was born and educated in England. After attending London University and the Royal Technical College in Glasgow, Scotland, he received a B.Sc. in 1914. The First World War occupied most of his time for the next four years, unfortunately mostly as a prisoner-of-war in both Germany and Holland. After this, he went to Oxford where he received an M. A. in Forestry in 1920. He then left for Poland where he was attached to the Polish army with the rank of Colonel. He received the Restitutcia Polski decoration. he remained in Poland until 1926, travelling extensively through Central Europe.

But the New World was beckoning and J. O. came to Canada where he joined Anglo-Canadian Pulp and Paper Mills Limited in 1927, a company which was just starting operations in Quebec City. He went from Logging Engineer right up to Woods Manager which position he occupied until his retirement in 1954. Although J. O. Wilson was considered by some as a "driver", he was known for his fairness at all times. He was always interested in the welfare of his staff and was one of the first to allow wives in logging camps when supervisory personnel had to be on the job for long periods. He was also instrumental in giving Forestry graduates responsible positions on logging operations. Many of his "students" later occupied positions among the higher "echelons" in the Industry. He remained active until recently when he went to live in Cobourg, Ontario, where his son, lan, practices medicine.

"J. O." was well known for his interest in mechanization and was responsible for many innovations in Forestville. $\mathrm{He}$ was an active member of many professional and industrial associations, such as the Canadian Institute of Forestry (honorary member), L'Ordre des ingénieurs-forestiers du Québec (president 1935-36), Canadian Pulp and Paper Association, Woodlands Section (Chairman 1937- Honorary life member), American Society of Foresters.

As if the foregoing were not enough, looking back, we find J. O. Wilson as Professor of Logging Practice at the School of Forestry of Laval University in 1936 where for over 20 years, he gave his students the benefit of his practical knowledge and long and varied experience in logging operations. The field trips which he conducted at the end of the school year were particularly enjoyable. However, he will be especially remembered by all of us for his many articles about logging, education, mechanical equipment and road building.

"J. O." our many memories and sincerest thanks go with you!

August 1980 The Forestry Chronicle 